\title{
Scientific documentation required during the exploration of caves and technical work carried out in tourist show caves - examples from central Poland
}

\author{
Dokumentacja naukowa jako konieczny element podczas eksploracji \\ oraz prac udostępniających jaskinie turystyczne - \\ przykłady z Polski środkowej
}

\author{
Jan Urban ${ }^{1 *}$, Andrzej Tyc ${ }^{2}$, Andrzej Kasza ${ }^{3}$, Marceli Ślusarczyk ${ }^{4}$ \\ ${ }^{1}$ Polish Academy of Sciences, Institute of Nature Conservation; al. Adama Mickiewicza 33, 31-120 Kraków; \\ ${ }^{2}$ University of Silesia, Faculty of Earth Sciences, Department of Geomorphology; ul. Będzińska 60, 41-200 Sosnowiec; \\ ${ }^{3}$ Świętokrzyski Speleoclub in Kielce; ul. Żurawia 23, 25-653 Kielce; \\ ${ }^{4}$ Fundacja Przyroda i Człowiek; Kostkowice, ul. Górska 21, 42-425 Kroczyce; \\ 'urban@iop.krakow.pl; ${ }^{2}$ andrzej.tyc@us.edu.pl; ${ }^{3} a n d r z e j k a @ p o c z t a . o n e t . p l ;{ }^{4}$ slusar0@poczta.onet.pl
}
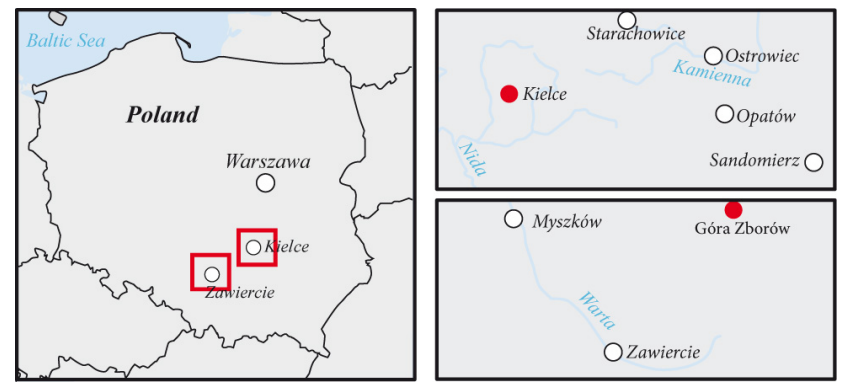

Article history:
Received: 20 June 2017
Accepted: 15 December 2017
Available online: 20 June 2018
C 2017 Authors. This is an open access publication, which can be
used, distributed and reproduced in any medium according to the
Creative Commons CC-BY 4.0 License requiring that the original
work has been properly cited.

Abstract: The procedure of scientific documentation of caves explored and/or arranged for touristic use is proposed and recommended in this paper. This procedure has been verified on the basis of work done during the arrangement of the Underground Touristic Trail combining three caves in the Kadzielnia Park, city of Kielce, Świętokrzyskie (Holy Cross) Mountains, and Jaskinia Gtęboka (Deep Cave) in the "Góra Zborów" nature reserve, Kraków-Częstochowa Upland. The objective of the cave documentation is the preservation of scientific evidence of the geological history of karst systems and the region, which are recorded in sequences of cave sediments (including their physical, petrographic and mineralogical properties, palaeontological remains and archaeological artefacts), mineralogical and isotopic composition of speleothems and specific features of cave morphology. These elements are often totally or partially destroyed (i.e. removed, changed in shape) during cave exploration and/or any technical work carried out in tourist caves. This makes it necessary to document thier scientific study, which is also required by law. The procedure of such documentation and study proposed and verified in this paper include the photographic documentation of sediments and cave morphologies, sampling of sediments, as well as their basic petrographical-palaeontological analyses, which make it possible to plan exploration, technical work and further research.

Key words: caves, cave arrangement for public, geotourism, scientific values, documentation, geoheritage

Treść: Artykut proponuje procedurę dokumentacji naukowej jaskiń, które sq eksplorowane oraz przygotowywane do udostępnienia turystycznego. Procedura ta została zweryfikowana podczas prac udostepniajacych Podziemna Trase Turystyczna taczaca trzy jaskinie w parku Kadzielnia w Kielcach na terenie Gór Świętokrzyskich oraz Jaskinię Głęboka w rezerwacie przyrody „, Góra Zborów” na Wyżynie Krakowsko-Częstochowskiej. Celem naukowej dokumentacji jaskiń jest zachowanie świadectw geologicznego rozwoju i ewolucji systemu krasowego oraz regionu, w którym system ten powstat. Świadectwa te zapisane sa w sekwencjach osadów namuliskowych 
(w postaci ich cech fizycznych, petrograficznych oraz mineralogicznych, a także artefaktów paleontologicznych i archeologicznych), $w$ mineralnym oraz izotopowym składzie nacieków $i$ w morfologii jaskiniowej. Te elementy sa często całkowicie lub częściowo niszczone (osady sq usuwane, rzeźba ścian zmieniana) w czasie prac eksploracyjnych i/lub prac górniczo-technicznych w jaskiniach udostępnianych turystycznie. To stwarza konieczność wykonywania dokumentacji i badań naukowych, które wynikają również z przepisów prawnych. Proponowana procedura prac dokumentacyjno-badawczych obejmuje: dokumentacje opisowa i fotograficznq sekwencji osadów oraz rzeźby jaskini, opróbowanie osadów, a także podstawowe analizy petrograficzne i paleontologiczne, które umożliwiaja właściwe planowanie oraz prowadzenie dalszych prac eksploracyjnych i górniczo-technicznych, a także dalszych badań.

Stowa kluczowe: jaskinie, udostępnienie turystyczne jaskiń, geoturystyka, wartości naukowe, dokumentacja, dziedzictwo geologiczne

\section{Introduction}

The caves and palaeokarst forms are specific traps in which the evidence of geological history (palaeogeography, palaeoenvironment, palaeontology, etc.) are gathered. They are represented by cave sediments containing allogenic (originated out of the cave and transported into it) and autigenic rock particles (from host rocks), fossils, as well as archaeological artefacts. Furthermore, the studies of speleothems and other minerals originated directly in the caves (in particular, analyses of isotopes) provide important data on their age and environmental condition at the time of their development. The other very important field of research providing significant data on the genesis and development of caves - not only karst ones, but non-karst caves, as well - are studies of cave patterns and passage morphologies. In this sense, the cave sediments and morphologies are geological heritage important for our knowledge of the Earth's history. In the other case, artificial cavities (mines, military works, underground dwellings, transit underground works, etc.), their shape and contents (sediments, among which are often secondary minerals, e.g. forming speleothems) prove their origin and history and, therefore, can be important matter of scientific investigations (Głazek, 1973; Urban, 2004, 2006; Tyc, 2016a).

During cave exploration, such elements, particularly depositional sequences of sediments, are often destroyed or even the sediments are totally removed from their original positions. Somewhere/sometimes, the speleothems and natural morphologies of host rocks are also destructed in order to widen the passages. Similar changes are made during the preparatory technical work in the caves or artificial cavities arranged for touristic use. On the other hand, such works that include the digging of cave sediments, provide a unique opportunity to outcrop and document their depositional sequences, as well as their petrographical, palaeontological and archaeological content. The other results of such works are changes in the cave topoclimate and fauna. Therefore, the preparatory works in two the most important (in the scientific, educational and touristic sense) tourist show caves in Poland: Raj (Paradise
Cave) in the Świętokrzyskie (Holy Cross) Mts. and Jaskinia Niedźwiedzia (Bear Cave) in the Sudetes, performed in the second half of the $20^{\text {th }}$ century, were associated with detailed cave mapping (partial inventory of morphologies, speleothems), climatic observation and, most of all, with comprehensive scientific research that comprised the geological (petrographical), palaeontological and archaeological investigations. The results of these documentation and scientific works were published in monographs, issued more or less in the time of the opening of the touristic trails in both caves (e.g. Studies..., 1972; Rubinowski, 1974; Jahn et al., 1989).

In the first ten years of the $21^{\text {th }}$ century, similar preparatory works (arrangement) for public access were performed in two cave systems: Underground Touristic Trail in the Kadzielnia Park, Kielce city in the Świętokrzyskie Mountains and in Jaskinia Głęboka (Deep Cave), located in the "Góra Zborów" natural reserve in the KrakówCzęstochowa Upland. In both cases, the exploration and further technical - mining and construction - work was associated with scientific documentation of the caves. The procedures of these documentations and scientific studies are described in this paper and then verified by the scientific results of these studies. The principal criteria of their verification are the state of preservation of scientific records available and then (partially) destroyed during the technical works in the caves, as well as the progress of knowledge of the origin and development of caves. As the proposed procedure of documentation and scientific study is sufficient for the preservation of the principal scientific data "trapped" in the caves, the authors recommend it as required in all further arrangement works in caves and artificial cavities prepared for public, touristic access.

\section{Settings and the state of art}

\section{Underground Touristic Trail in the Kadzielnia Park}

The Underground Touristic Trail is situated within Upper Devonian limestone massif forming the eastern face of the quarry which cut Kadzielnia Hill. The quarry, 
abandoned in the 60 's of the $20^{\text {th }}$ century, is now included into the city-park of Kielce, a capital of the Świętokrzyskie Province. In geological terms, the Devonian rocks represent the Palaeozoic core of the Świętokrzyskie Mountains (Fig. 1) tectonically deformed mainly during the Variscan tectonic movements (Urban \& Gągol, 2008). Morphologically, the Świętokrzyskie Mts. are low mountains composed of structurally controlled hill ranges built of stronger rock formations in the geological sequence of the region, such as e.g. Middle and Upper Devonian limestones and dolomites, that occur in the limbs or axial parts of several synclines. Kadzielnia Hill is an element of the Kadzielnia Hill Range, situated in the south-western part of the region in the area of outcrop of the Kielce syncline (Urban, 2014).

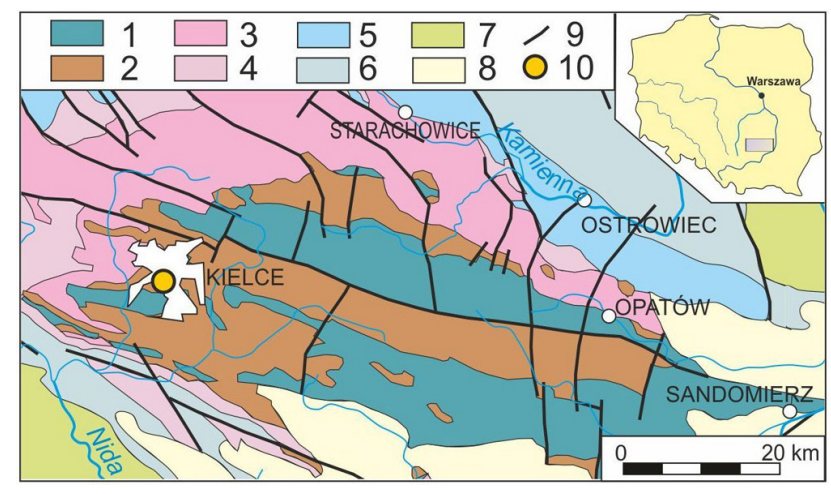

Fig. 1. Geological settings of the Świętokrzyskie (Holy Cross) Mountains with the location of the Kadzielnia Park and Underground Touristic Trail (map after Urban, Gągol, 2008). Explanation of symbols: 1 - Cambrian, Ordovician and Silurian, 2 - Devonian, Lower Carboniferous, 3 - Permian and Lower Triassic, 4 - Middle and Upper Triassic, 5 - Lower and Middle Jurassic, 6 - Upper Jurassic, 7 - Cretaceous, 8 - Neogene, 9 - principal fault, 10 - Kadzielnia Park with Underground Touristic Trail

The lower part of Kadzielnia Hill is built of massive and thick bedded limestones (Frasnian, Lower Famennian), which are overlain by thin-bedded limestone-marlclay series (Famennian). The Neogene karst system occurring within the massive and thick-bedded limestone is partly filled by Quaternary sediments. Therefore, its conduits are accessible as 26 caves with entrances in the faces of the Kadzielnia quarry. The caves are parts of this system not filled by sediments, and are usually several to several ten meters long (Fig. 2) (Urban et al., 2011a, b). The water table lies near the bottom of the quarry (which is suggested by relatively stable water-pool occupying its lowermost part), therefore, the karst conduits that are accessible in the quarry, are now situated in the vadose zone.

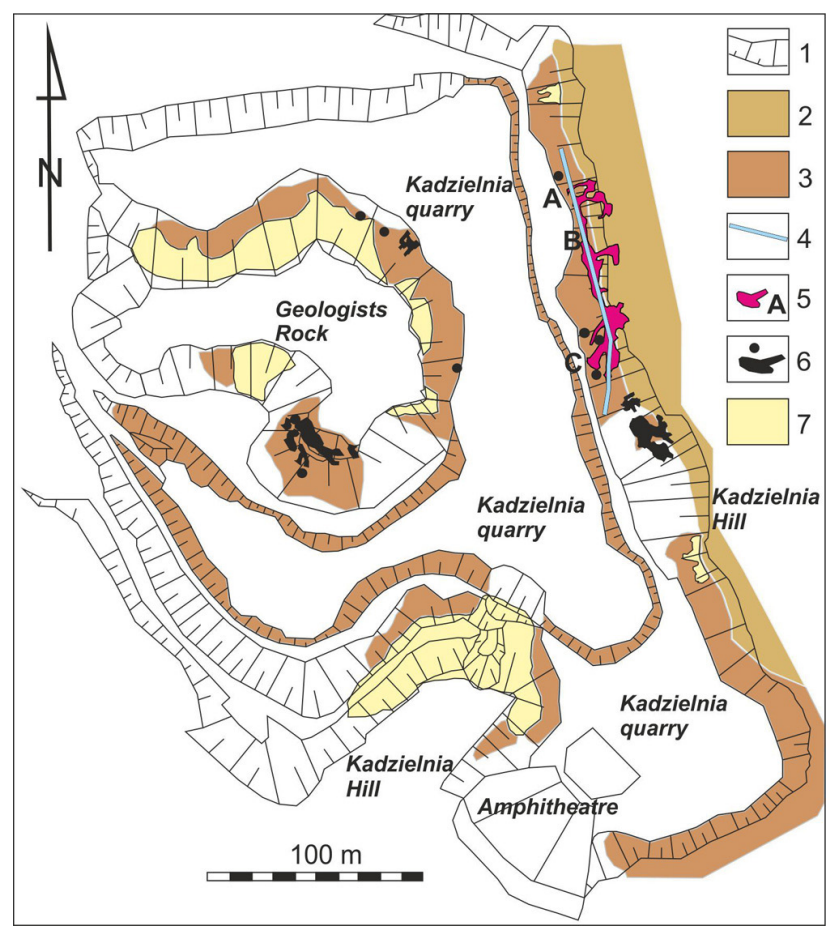

Fig. 2. General situation of the Underground Touristic Trail in the Kadzielnia Park (map after Urban et al., 2011b). Explanation of symbols: 1 - quarry face and other scarp; 2 - outcrop of the Famennian limestone-marl-clay thin-bedded series; 3 - outcrop of the Frasnian and Lower Famennian massive and thick-bedded limestone; 4 - fault in the eastern quarry face; 5 - caves explored and modified due to the Underground Touristic Trail preparation: A - Jaskinia Odkrywców Cave, B - Prochownia Cave, C - Szczelina na Kadzielni Cave; 6 - other caves; 7 - outcrops of sediments filling karst dolines and smaller cavities (nowadays partly overgrown by plants)

Several caves are spatially connected with the fault stretching NNE-SSW, visible in the eastern quarry face. Assuming that the fault zone favoured the karst system development (which was documented in fault surface outcropped in the quarry face - Fig. 3), the Geopark Kielce - an office of the Kielce municipality managing the Kadzielnia Park - planned to merge these caves by the exploration of still not accessible parts of the karst system genetically connected with this fault zone, in order to arrange an underground touristic trail. Three caves were selected to merge: Prochownia (Gunpowder Magazine, formerly $28 \mathrm{~m}$ long), Szczelina na Kadzielni (Crevice in the Kadzielnia, $180 \mathrm{~m}$ ) and Jaskinia Odkrywców (Explorers' Cave, 14 m) (Fig. 4). These caves are situated some 10-20 $\mathrm{m}$ above the water table. The work started in 2004 and was first carried out by the members of the Świętokrzyski Speleoclub in Kielce and then, since 2006, by the staff of cavers and miners of a professional mining company from Kraków. 


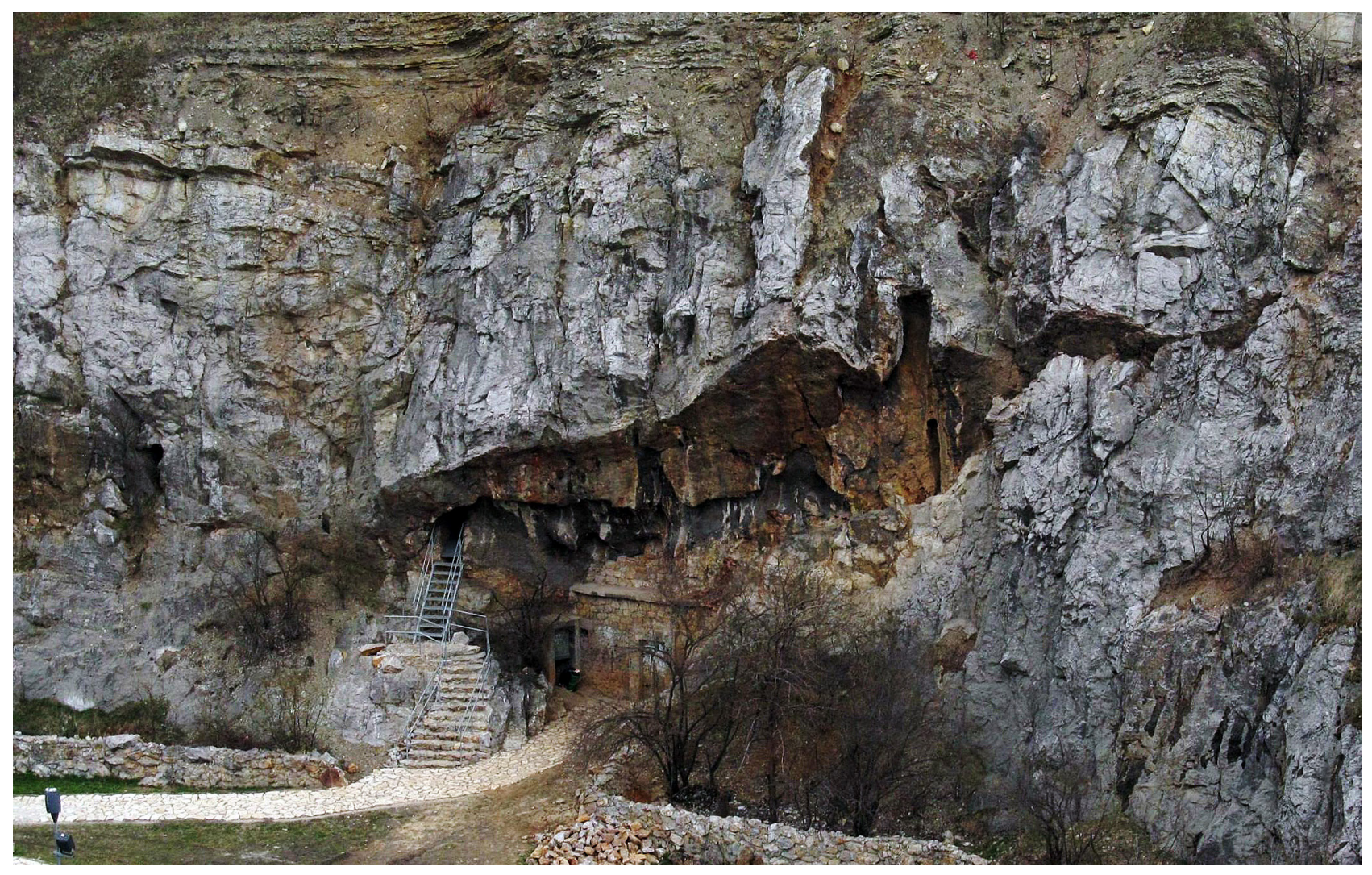

Fig. 3. The entrance to the Underground Touristic Trail in the Kadzielnia Park in 2012. Above the entrance the fault surface with characteristic contour of karst conduits is visible; in the uppermost part of the quarry face the Famennian limestone-marl-clay thin-bedded series is visible, photo J. Urban

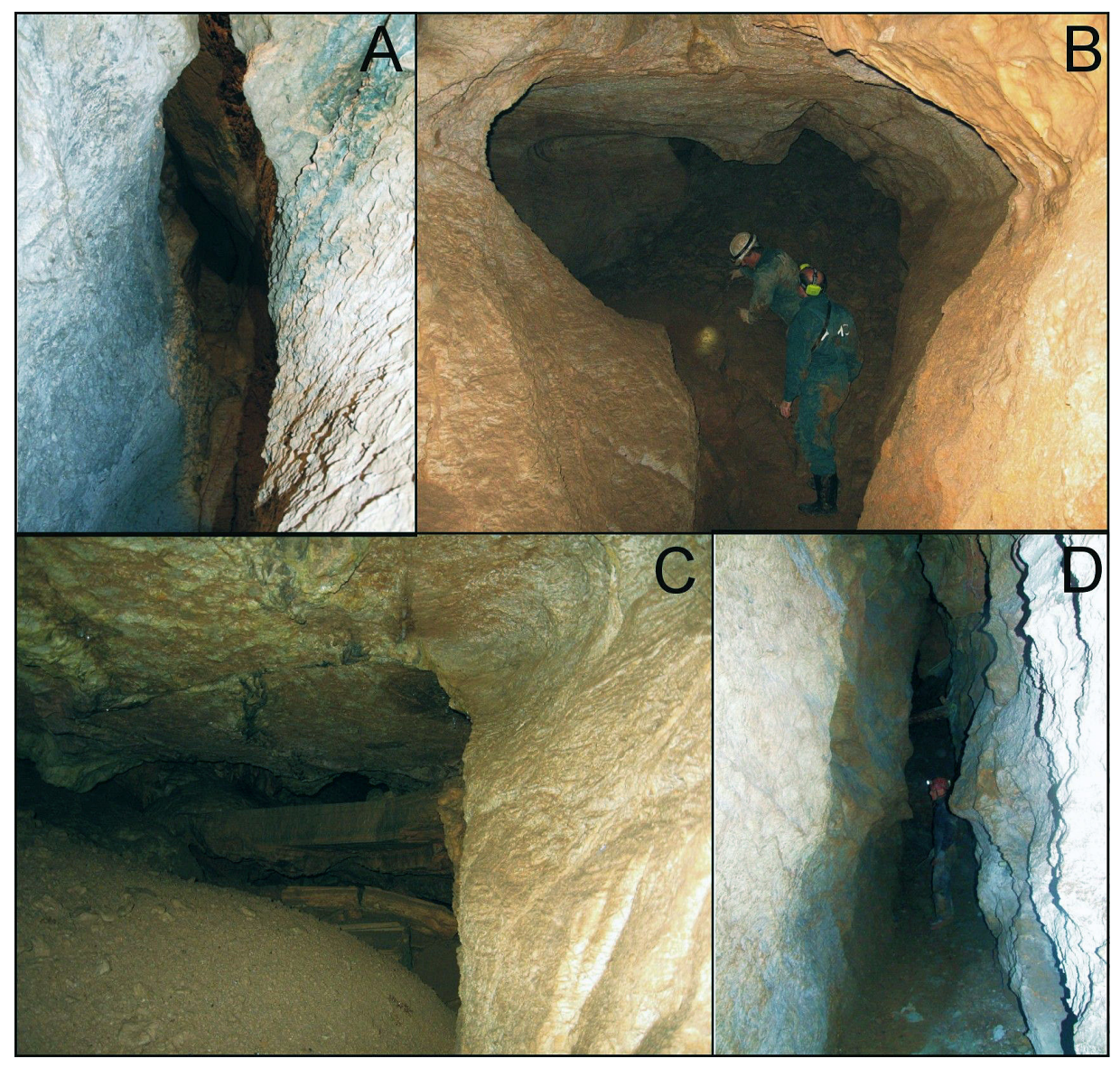

Fig. 4. Passages of caves that constitute the Underground Touristic Trail in the Kadzielnia Park: A - karst crevice of the Jaskinia Odkrywców Cave; B - typical of a shallow phreatic zone karst conduit of the Prochownia Cave; C - large calcite flowstone formed on horizontal surface of cave sediments of the Prochownia Cave; D - karst crevice of the Szczelina na Kadzielni Cave, photo A. Kasza - B, C; J. Urban - A, D 
These works included most of all the excavation and removal of clayey and debris-clayey sediments, in some places also lithified carbonate-clayey sediments that fill the karst conduits. In several places, the passage ceilings and walls (formed of densely jointed limestone or cobbles and boulders filling vertical karst conduits) had to be supported and stabilised by typical mining constructions (Fig. 5). In a few sections, the passages were also artificially widened. The other preparatory work done in the passages of the touristic trail included the paving and arrangement of stairs, lighting system and an educational site system (Fig. 6).

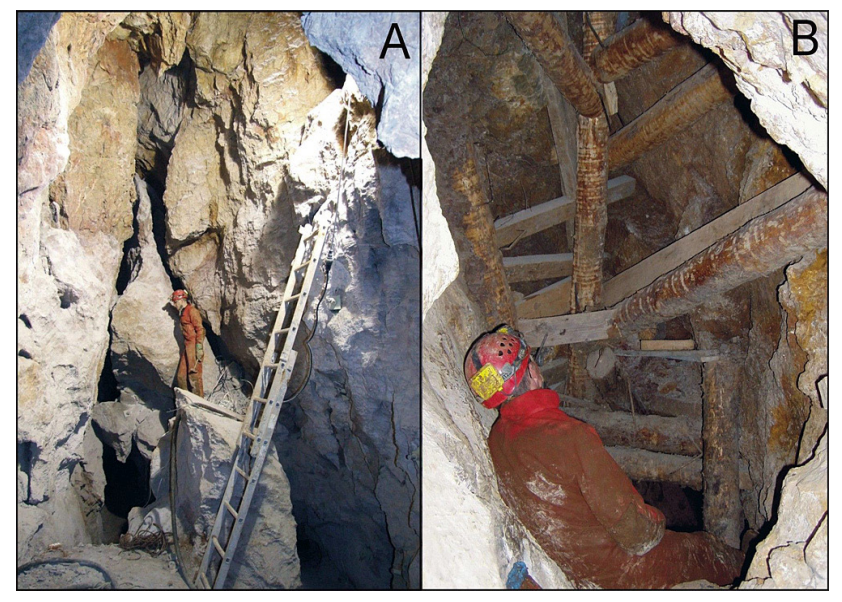

Fig. 5. The Underground Touristic Trail during the preparation technical works: A - the largest chamber of the Szczelina na Kadzielni Cave; B - the construction stabilising the karst chimney, which opened during the technical works, photo J. Urban

Finally, the Underground Touristic Trail in the Kadzielnia Park, composed of Prochownia (Gunpowder Magazine), Szczelina na Kadzielni (Crevice in the Kadzielnia) and Jaskinia Odkrywców( Explorers' Cave) caves, as well as karst conduits explored during the preparatory works, is the cave system $392 \mathrm{~m}$ long (Fig. 6) and has been officially available for public use since 2011, in the period of April $1^{\text {st }}$ to October $30^{\text {th }}$. The principal educational, geotouristic elements of this tourist show cave, are as follow: a) sedimentary structures and fossils outcropped in the cave walls and presenting the shallow marine depositional environment of Devonian limestone, b) tectonic structures (fault surface and zone), sediments (tectonic breccia) and connected with them hydrothermal veins filled with calcite and galena, c) karst morphologies of conduits that indicate the origin and development of the cave, d) Early Pleistocene and Late Pleistocene-Holocene cave sediments with fossils, as well as e) calcite speleothems of various shape and age (Fig. 7).

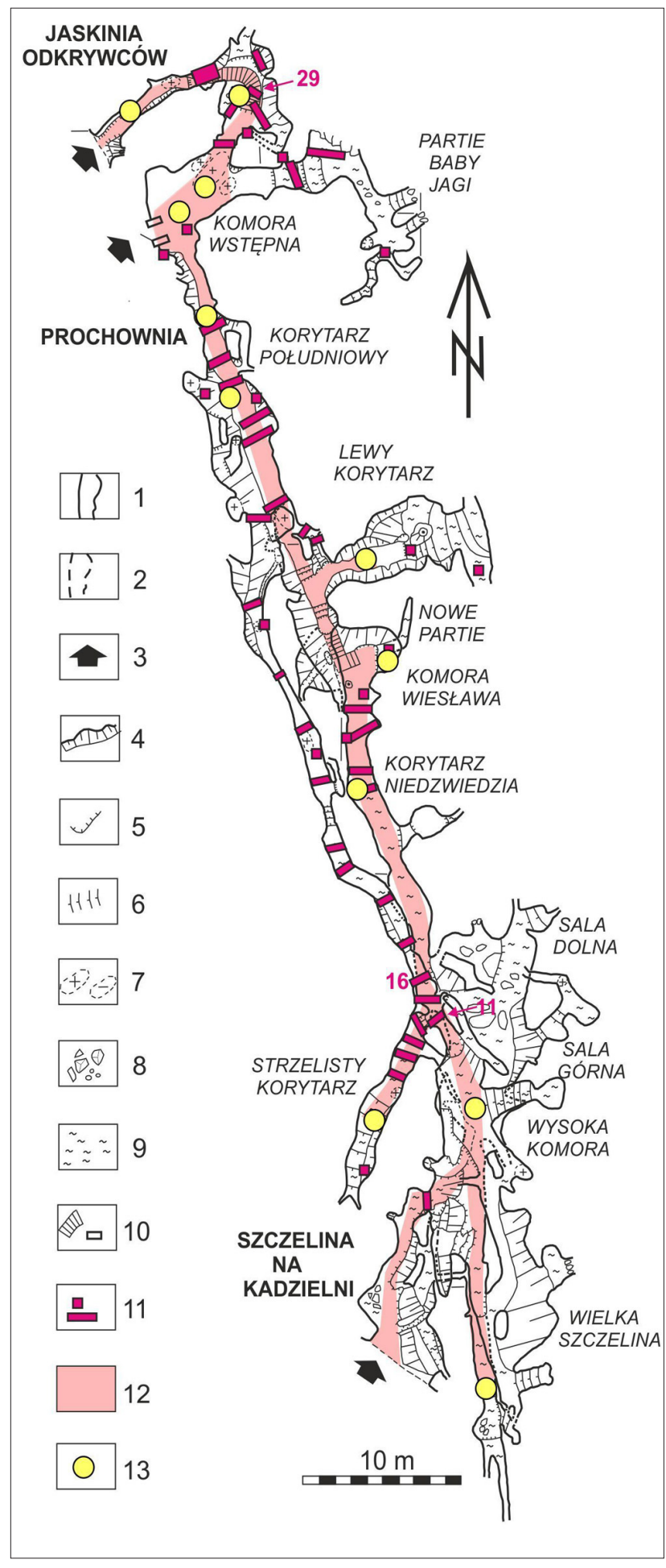

Fig. 6. Map of the Underground Touristic Trail in the Kadzielnia Park with distribution of documentation sites and educational sites (after Urban, Kasza - archival data and Urban et al., 2011b). Explanation of symbols: 1 - contour of cave passage; 2 - contour of cave passage overlapped with upper one; 3 - cave entrance; 4 - steep dip of the passage wall; 5 - scarp; 6 - dip of the passage floor; 7 - cave chimney or well; 8 - boulders and cobbles; 9 - clayey sediment (on the floor); 10 - artificial elements: wall, stairs; 11 - documentation sites (the sites shown on Fig. 5 are numbered); 12 - Underground Touristic Trail (show cave); 13 - educational sites of the Underground Touristic Trail (show cave) 


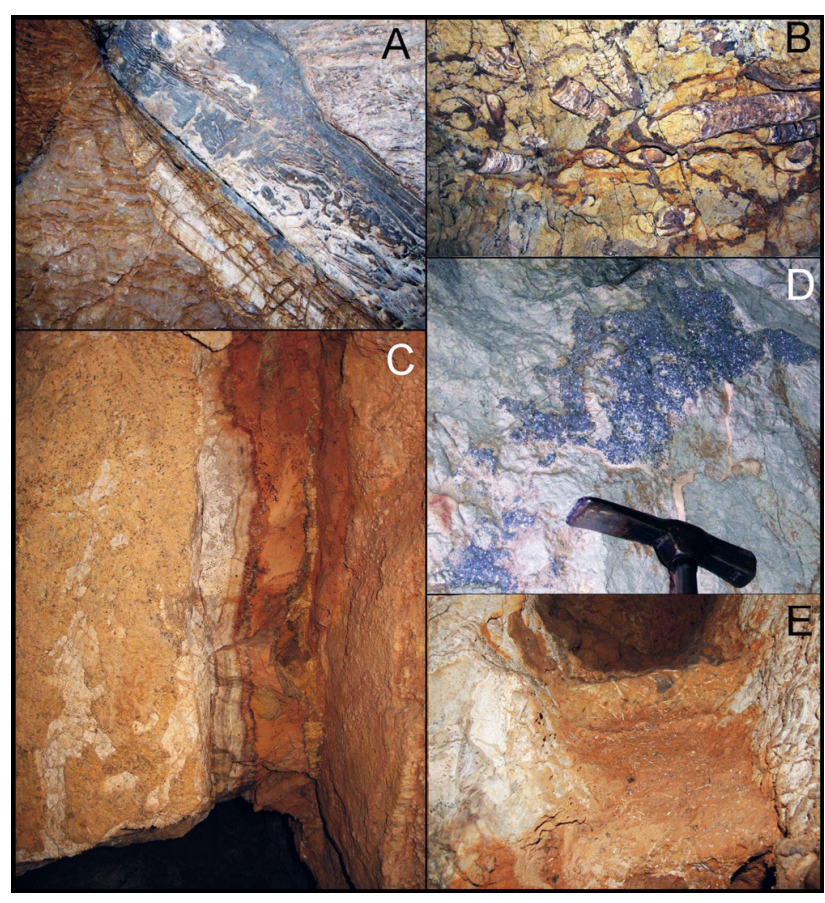

Fig. 7. The principal educational-touristic features of the Underground Touristic Trail: A - specific depositional structures of the Devonian limestones visible on the wall of the Jaskinia Odkrywców Cave; B - fossils (cephalopods) exposed in the Prochownia Cave; C - hydrothermal calcite vein developed along the fault surface that crosses the Prochownia Cave; D - galena crystals on the wall of the Prochownia Cave; E - Early Pleistocene bone breccia in beige marl filling the karst crevice, photo A. Kasza - C; J. Urban-A, B, D, E

\section{Jaskinia Gtęboka \\ in the "Góra Zborów" nature reserve}

Jaskinia Głęboka is located on the north-western edge of Góra Zborów Hill (462 $\mathrm{m}$ a.s.l.), in the central part of the Kraków-Częstochowa Upland. The area is a part of the so-called Permian-Mesozoic structural complex (Matyja \& Wierzbowski, 2004; Krajewski \& Matyszkiewicz, 2009; Fig. 8), expressed in the landscape as a monoclinal plateau lying at the elevation of 350-500 m a.s.l. Rocky hills and tors on the plateau are significant features of this landscape. The present-day morphology of Góra Zborów Hill is an effect of complex fault tectonics and intense karst processes. The cave is situated within Upper Jurassic (Oxfordian) limestone massif, outcropped on the quarry walls surrounding the cave entrances (Fig. 9). Different facies of these limestones built Góra Zborów Hill. Both in the quarry and on the cave walls, the massive biohermal limestones contact with bedded limestones. A dense network of fissures and faults is present in this part of the massif. Jaskinia Głęboka follows the lithological contacts and structural lineaments.

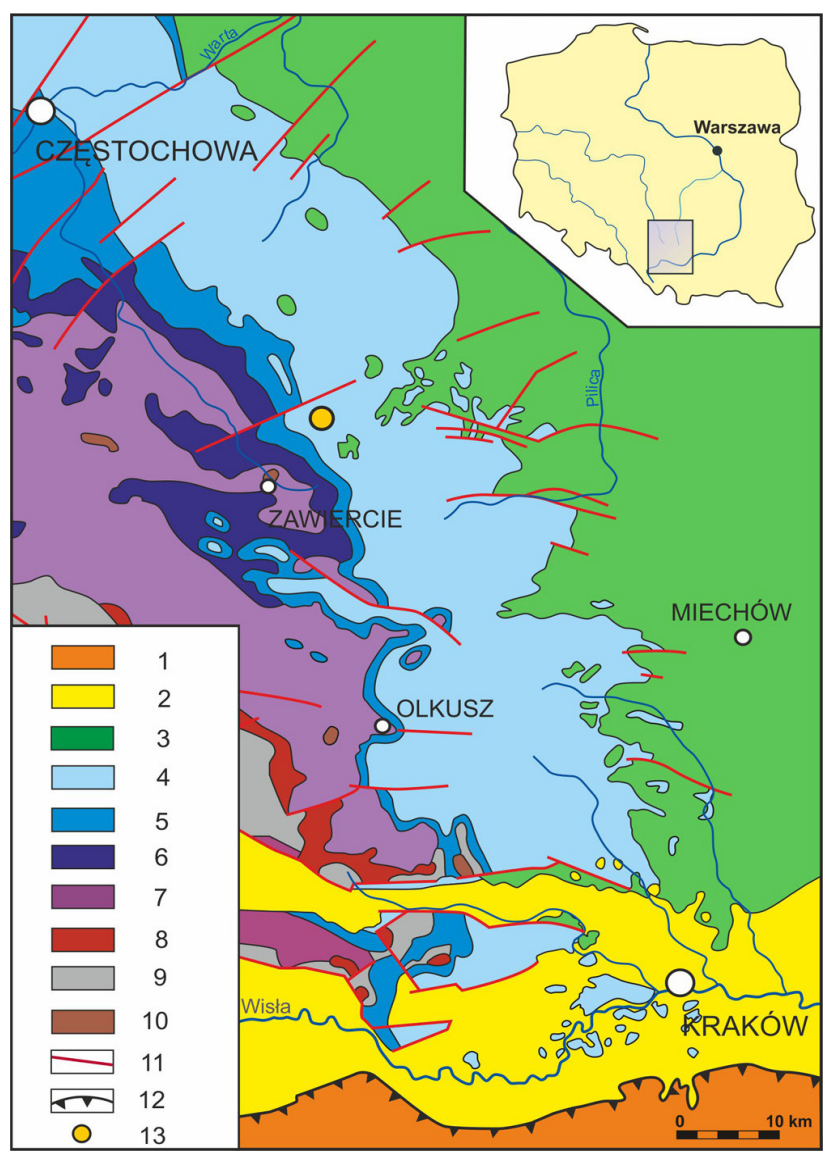

Fig. 8. Geological settings of the Kraków-Częstochowa Upland with the location of the Jaskinia Głęboka Cave (map after Krajewski, Matyszkiewicz 2009, modified). Explanations of symbols: 1 - Carpathian Flysch; 2 - Neogene; 3 - Cretaceous; 4 - Upper Jurassic; 5 - Middle Jurassic; 6 - Lower Jurassic; 7 - Triassic; 8 - Permian; 9 - Carboniferous; 10 - Devonian; 11 - faults; 12 - Carpathian overthrust; 13 - Jaskinia Głęboka Cave

A small quarry in Góra Zborów Hill was shortly operated during the Second World War and the cave was discovered as well as partly destroyed during limestone exploitation in 1942. For the first time, the cave was inventoried and recognized as Jaskinia Głęboka w Berkowej Górze (Deep Cave in Berkowa Hill) by K. Kowalski in 1948 (Kowalski, 1951; Sznober \& Tyc, 2010). The length of its passages was estimated in that time at $40 \mathrm{~m}$. Subsequently, new passages were discovered in the cave in 1960s: Esso and Sala za Esso (Room behind Esso) (Figs 10, 11). The cave has actually $190 \mathrm{~m}$ in length and $22.4 \mathrm{~m}$ in vertical extent $(+2,9 \mathrm{~m}$ and $-19,5 \mathrm{~m})$ (Sznober $\&$ Tyc, 2010).

The very first attempts to arrange a touristic trail in Jaskinia Głęboka were undertaken by the Polish Tourist and Sightseeing Society in early 1970s. They built concrete stairs with barriers to take tourists from the cave entrance in abandoned quarry to the bottom of the largest chamber, Sala Poludniowa (Southern Room). 


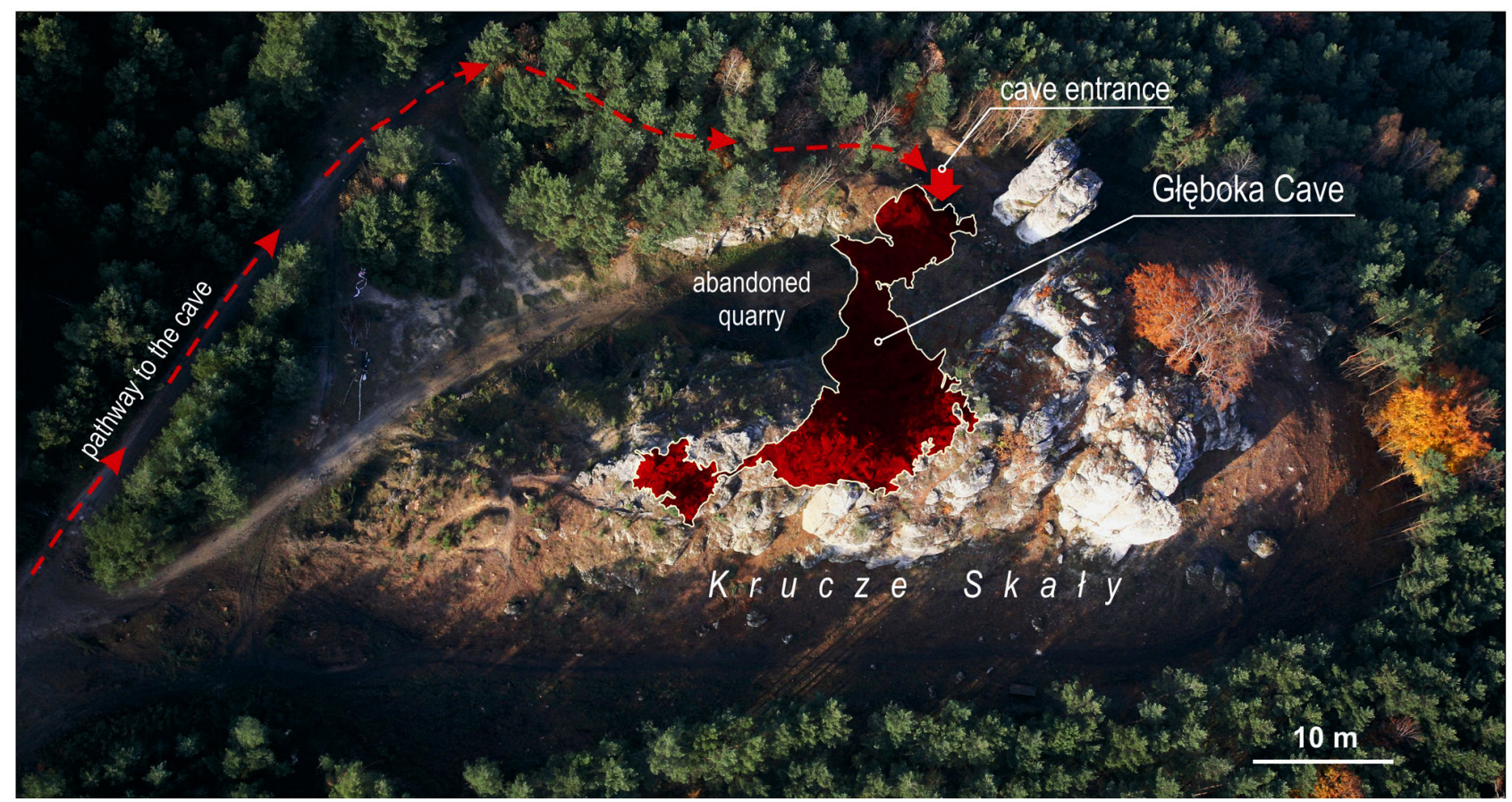

Fig. 9. Location of the Jaskinia Głęboka Cave in the Krucze Skały rock hill in the northern part of the "Góra Zborów" nature reserve (after Sznober, Tyc 2010, modified)

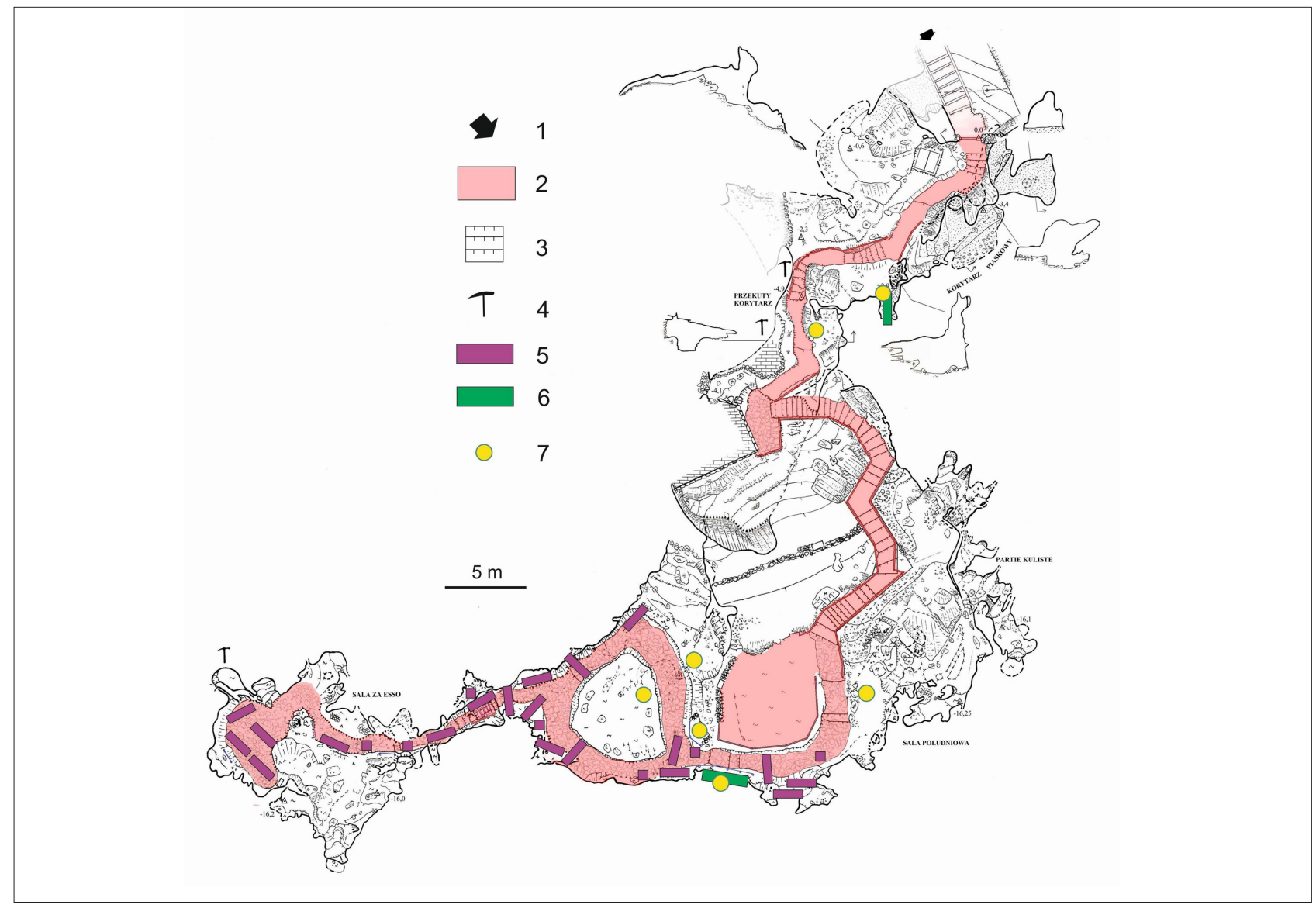

Fig. 10. Map of the Jaskinia Głęboka Cave with the location of touristic trail and documentation sites within the show cave (cave survey after Sznober, Tyc 2010, modified). Explanation of symbols: 1 - cave entrance; 2 - touristic trail; 3 - stairs along the touristic trail; 4 -artificial excavations; 5 - documentation sites with the sequences of clastic cave sediments; 6 -documentation sites with the profiles of investigated thick flowstones; 7 - educational sites on the touristic trail 


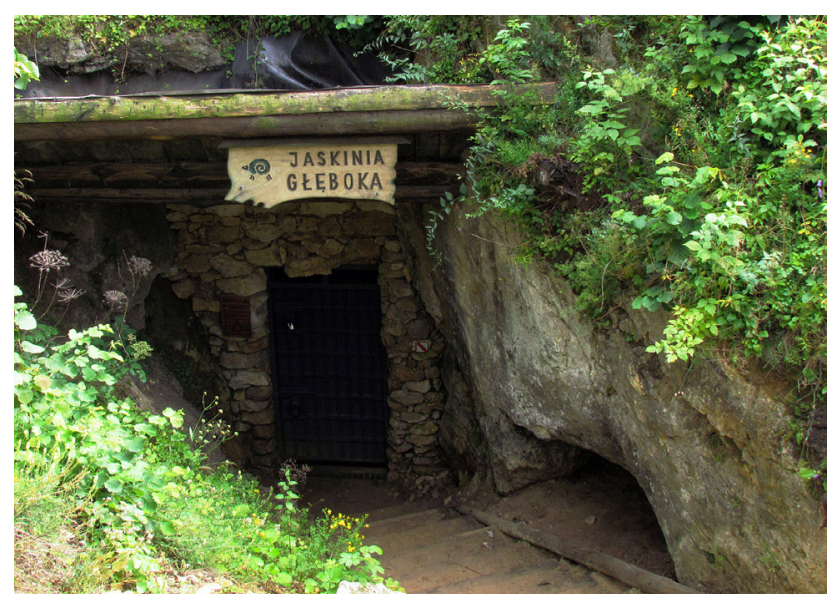

Fig. 11. Entrance to the Jaskinia Głęboka Cave after opening of touristic trail in 2012, photo A. Tyc

Visits in the cave were organized individually with their own light. At that time, Jaskinia Głęboka was divided into two different objects - the exact Jaskinia Głęboka with the Sala Południowa chamber and short passage, actual Korytarz Wejściowy (Entrance Passage), with one entrance in the quarry and the second in Lej Szpatowców (Calcite Miners' Sinkhole) - cone shaped depression made by calcite miners in early 1950s. Thus the whole cave had four entrances at that time. Due to the long lasting (over 30 years) activity of visitors, the cave values were degraded, the cave was littered and dug in many places (Sznober \& Tyc, 2010). In the years 2006-2008, the tourist trail infrastructure was renewed, and the cave was cleared of litter and part of debris. The cave was still open and not controlled, so that the cave's values and infrastructure started to be quickly degraded. Additionally, in the first decade of the $21^{\text {st }}$ century, the roof of the entrance part of the main cave started to be unstable and was threatened by a total collapse. In such circumstances, the Authority of the Regional Directorate for Environmental Protection in Katowice, responsible for the protection of the "Góra Zborów" nature reserve, decided to stop touristic visits and to close the main entrance of the cave in 2009.

Jaskinia Głęboka was arranged as a real show cave with lighting, guided touristic and educational tours, tickets - in two stages in the years 2010 and 2012. In 2010, the concrete construction supporting the cave roof was built in the entrance part (close to the quarry surface), and three of four entrances were closed (with thermal isolation), and the above mentioned two parts of the cave were included into the entire cave system (Fig. 12). The main entrance to the show cave is located in the Lej Szpatowców, where doors especially designed for bats were installed (Figs 9, 10). The whole technical infrastructure was reconstructed and an
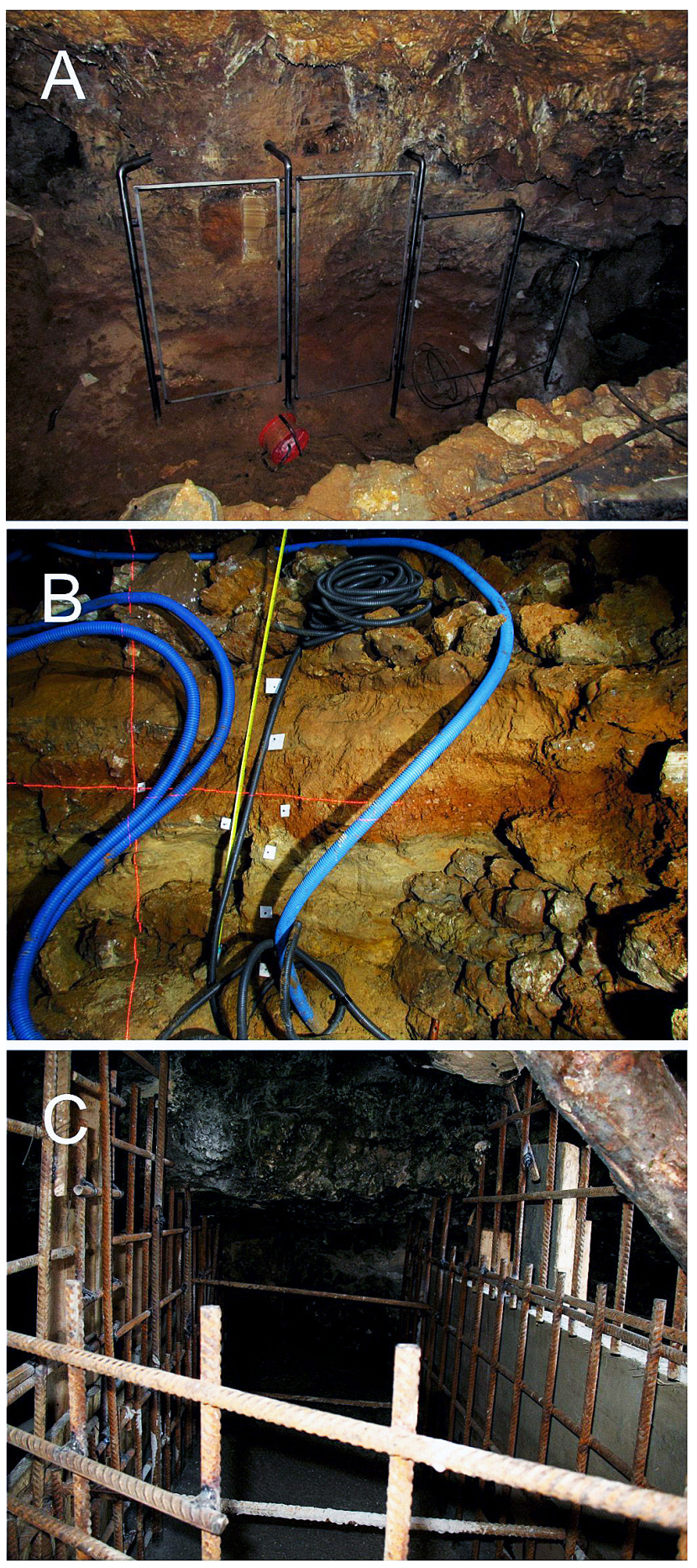

Fig. 12. Touristic trail in the Jaskinia Głęboka Cave during the preparation technical works in 2012 (A and B) and 2010 (C): A - installation of protective screen along thick flowstone profile in the main chamber of the cave; B - installation of lighting and monitoring system within cave sediments; $\mathrm{C}$ - preparation of the concrete construction supporting cave roof in the entrance part, photo A. Tyc

electric lighting system installed. The touristic trail at that stage was $60 \mathrm{~m}$ long and ran from the entrance to the bottom of the main chamber (Sala Południowa). At that stage of 
the preparation, the technical works were performed in the artificial debris, without influence on cave sediments and its morphology. The second stage in 2012 was related to the most important digging and down cutting of cave sediments during the technical works in the new passages prepared for tourists (Esso and Sala za Esso) (Fig. 12). In that period, the touristic trail was enlarged to $160 \mathrm{~m}$, and the system of cave environment monitoring (air temperature, humidity, $\mathrm{CO}_{2}$ content - based on data-loggers and devices installed in 5 sites) was built. Since 2010, Jaskinia Głęboka show cave is open daily in the period of April $15^{\text {th }}$ to October $30^{\text {th }}$ , and it is incorporated into the educational tour system of the "Góra Zborów" nature reserve. Despite the earlier degradation of the cave's values, this show cave is an important educational and geotouristic place in the whole region. Due to the technical work, as well as scientific documentation and studies of cave sediments and cave morphology, interesting geological and historical evidence can be shown and explained in the cave: a) relations between tectonic-lithological settings of the Oxfordian (Upper Jurassic) bioherm and karst/speleogenesis, b) specific cave morphology features related to groundwater level rising, infilling cave passages by sediments and dissolution on the contact between sediments and cave ceiling (deckenkarren), c) profiles of well-preserved continuous flowstone depositions recording climate and environment conditions in the region in Pleistocene, d) remnants of calcite (spar) mining in the mid of $20^{\text {th }}$ century (Fig. 13).
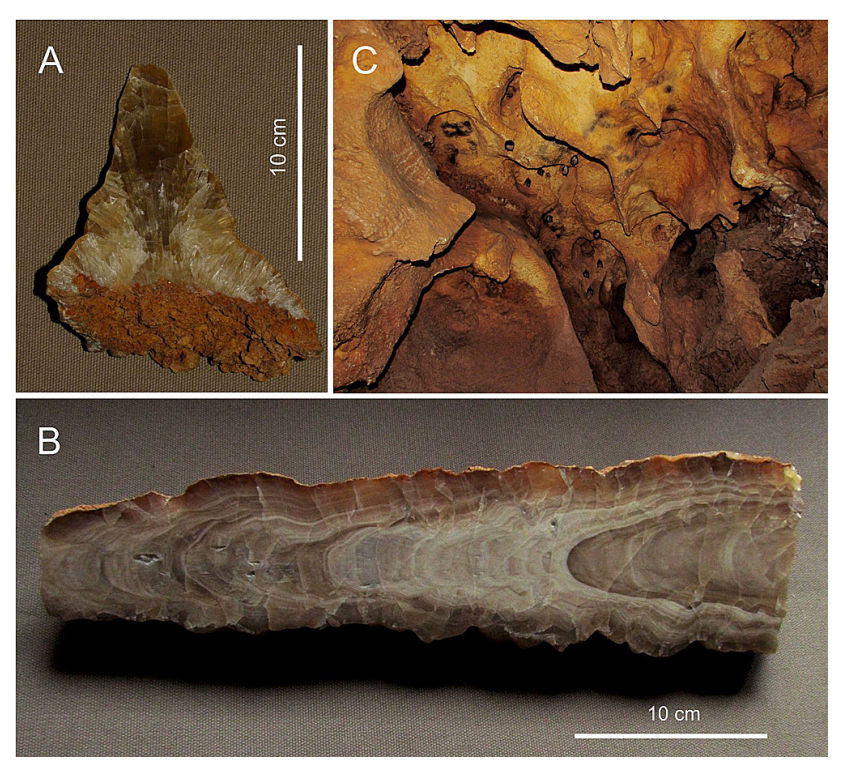

Fig. 13. Sections of speleothems and cave morphology features exposed on the touristic trail in the Jaskinia Głęboka Cave: A - recrystallized calcite in fossil stalagmite; $\mathrm{B}$ - fragment of broken stalagmite found within cave sediments; $\mathrm{C}$-above-sediment ceiling channels and pockets, photo A. Tyc

\section{Procedures}

\section{Underground Touristic Trail in the Kadzielnia Park}

The Geopark Kielce office and its expert, T. Wróblewski, were conscious that most of exploration and preparatory work would include the digging and removal of cave sediments, which are principal "traps" of the evidence of the geological history of karst systems and surrounding areas. Therefore, they planned very strict technical and scientific supervision of this work. The technical inspection was conducted by miners-geotechnicians from the AGH University of Science and Technology in Kraków, while the scientific documentation and superintendence was performed by cavers from the Świętokrzyski Speleoclub in Kielce and geologists from the Institute of Nature Conservation, Polish Academy of Sciences in Kraków. According to the project (Urban, Kasza, Gubała - archival data, Urban et al., 2011b), the scientific documentation includes the following activities: a) documentation (description, photography, drawing) of depositional sequences in sediment cross-sections each 1-3 $\mathrm{m}$ of the progress of digging; b) sampling of linear vertical specimens of sediments up to $0.5 \mathrm{~m}$ long and of a weight not less than $2 \mathrm{~kg}$ from each lithological unit macroscopically distinguished (differing in colour, structure, grain size, etc.) in every depositional sequences; c) description of morphology, structure and lithology of conduit walls (host rocks), such as depositional and tectonic structures, fossils (prepared by karst and weathering processes), veins, speleothems, etc. (Figs 6, 14). All these ordinary samples, after drying, were collected in the Geopark Office magazine as archival specimens, but most of them were divided into two parts: an archival specimen and samples for further analyses. Furthermore, some samples were taken for special analysis from the speleothems, veins and sediments not dug up.

According to the project, the basic, principal study of most samples should comprise the grain size analysis of the sands and gravel fractions (using sieves) and petrographic observations of grains using a binocular. These observations should be done immediately (in one-two days) after the sampling, so as to stop work (sediment removal) in case a micro-palaeontological site was to be dug. All samples in which Quaternary microfossils were found underwent special palaeontological analysis. A project postulated more advanced laboratory analyses, however their detailed scope was not defined in the initial state of work and was determined according to the lithological character of rocks and other special needs. 


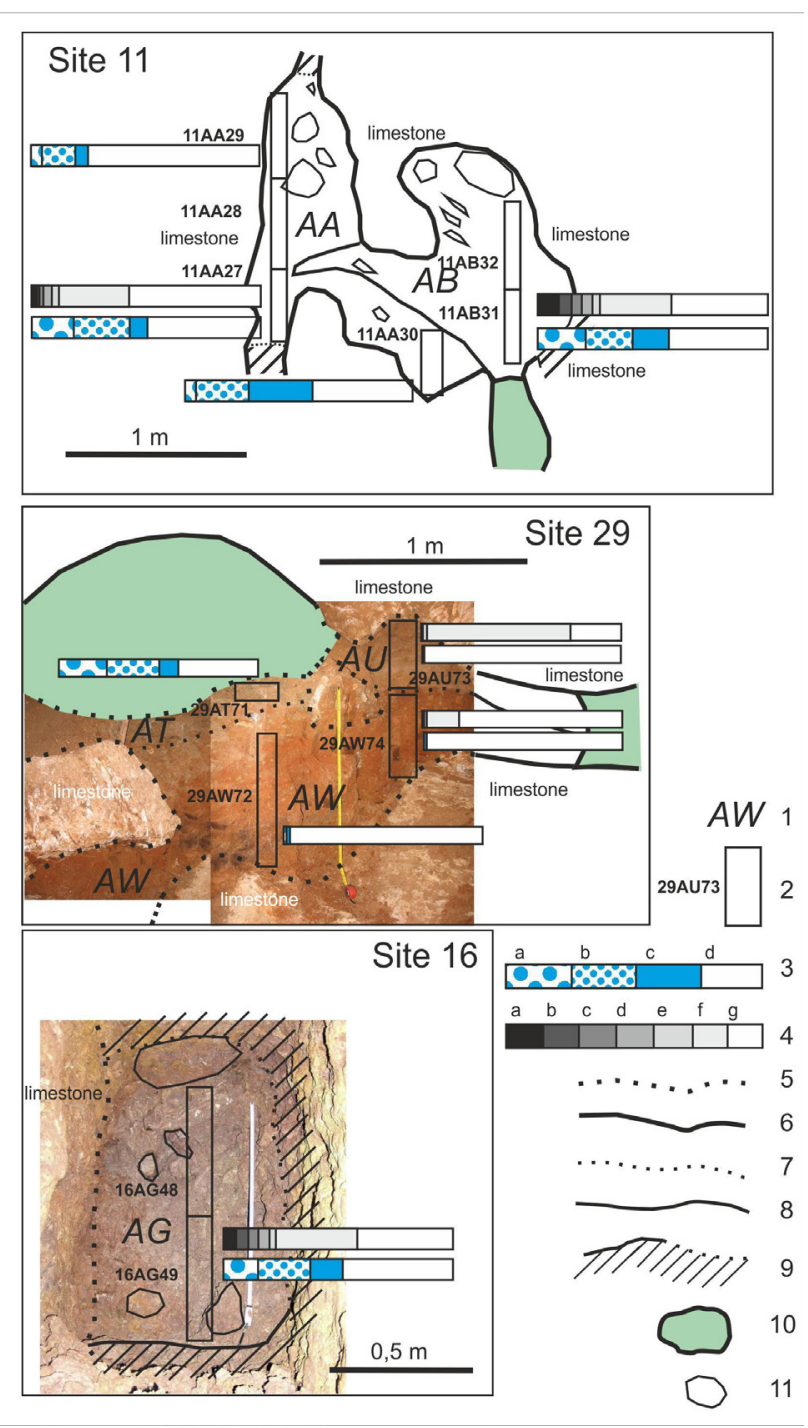

Fig. 14. Examples of the documentation sites (sites no. 11, 16 and 29) in the Underground Touristic Trail in Kadzielnia (see Fig. 6; after Urban, Kasza - archival data). Explanation of symbols: 1 - symbol of lithological unit; 2 - linear sample with its symbol; 3 - grains size of sample - main fractions ( $a$ - cobbles, $b$ - pebbles/ debris, $\mathrm{c}$ - sand, $\mathrm{d}$ - silt and clay); 4 - grain size of sample - fine fractions $(\mathrm{a}-$ sand $1-2 \mathrm{~mm}, \mathrm{~b}$ - sand $0.5-1 \mathrm{~mm}, \mathrm{c}-$ sand 0.25 $0.5 \mathrm{~mm}, \mathrm{~d}-$ sand $0.125-0.25 \mathrm{~mm}$, e - sand $0.063-0.125 \mathrm{~mm}$, f- silt, g-clay); 5 - cavity contour on the photograph; 6 - cavity contour out of the photograph; 7 - boundary of lithological unit on the photograph; boundary of lithological unit out of photograph; 9 - fragment of sediments which do not belong to the sequence (e.g. passage floor); 10 - cavity; 11 - cobble within the sediments

\section{Jaskinia Gtęboka in the "Góra Zborów" nature reserve}

As the entrance part of Jaskinia Głęboka started to be dangerous for visitors, in 2009, the Authority of Regional Directorate for Environmental Protection in Katowice ordered in the Institute of Mining in Katowice the technical protection project to prevent the collapse of roof. The project was later expanded to an arrangement of a new touristic trail in the cave. Engineers from this Institute, as well as those employed by the company performing all technical work in the cave in 2010 and in 2012 conducted technical inspection. At the same time the Regional Council for Nature Conservation in Katowice appointed a team of experts to supervise all steps of technical work and scientific documentation of the tourist cave arrangements. A team of experts consisted of geologists, geomorphologists, speleologists, palaeontologist, archaeologist and specialist on bats - seven researchers, some of them specialists in two scientific disciplines, from the University of Silesia, University of Wrocław, University of Szczecin, Institute of Nature Conservation of Polish Academy of Sciences in Kraków and Kraków Caving Club.

However, during the first stage of technical work in Jaskinia Głęboka (in 2010), almost all arrangements were done in artificial debris on the cave floor. In the next stage (in 2012), technical works were conducted with need to intervene in the natural cave sediments and flowstones on a distance of over $70 \mathrm{~m}$. During the first stage, the documentation and scientific studies were limited to frequent inspection of the cave and were mostly concentrated on cave morphology, microclimate and bats. In case of intense technical influence on the cave's environment during the second stage of the touristic trail arrangements, experts were in the cave almost every day and paid attention to every step of the project's realisation. Technical works were stopped a few times for hours or days to make precise documentation of sediments and micropalaeontological findings or to decide the next steps of work. Scientific documentation, similarly as in case of the Underground Touristic Trail in the Kadzielnia Park, was concentrated on very strict documentation of depositional sequences in cave sediments, sampling of sediments in every visible depositional sequences, as well as documentation and sampling of different solid deposits and speleothems. Documentation also included cave morphology and structural (tectonic and lithological) settings of cave passages. Twenty six sequences of cave sediments were strictly documented, of which almost 100 samples was taken for different analyses (grain size, petrographic, mineralogical and micro-palaeontological), as well as two profiles of flowstones were sampled for dating and isotope analyses (Figs 10, 15).

The establishment of a documentation archive is a very important part of the whole procedure required during exploration or any technical work in tourist caves. In case of Jaskinia Głęboka, it was decided in the project that the archive of all 26 sediment profiles, solid deposits and all collected samples is situated in the Department of Geomorphology, at the Faculty of Earth Sciences, University of Silesia in Sosnowiec. 


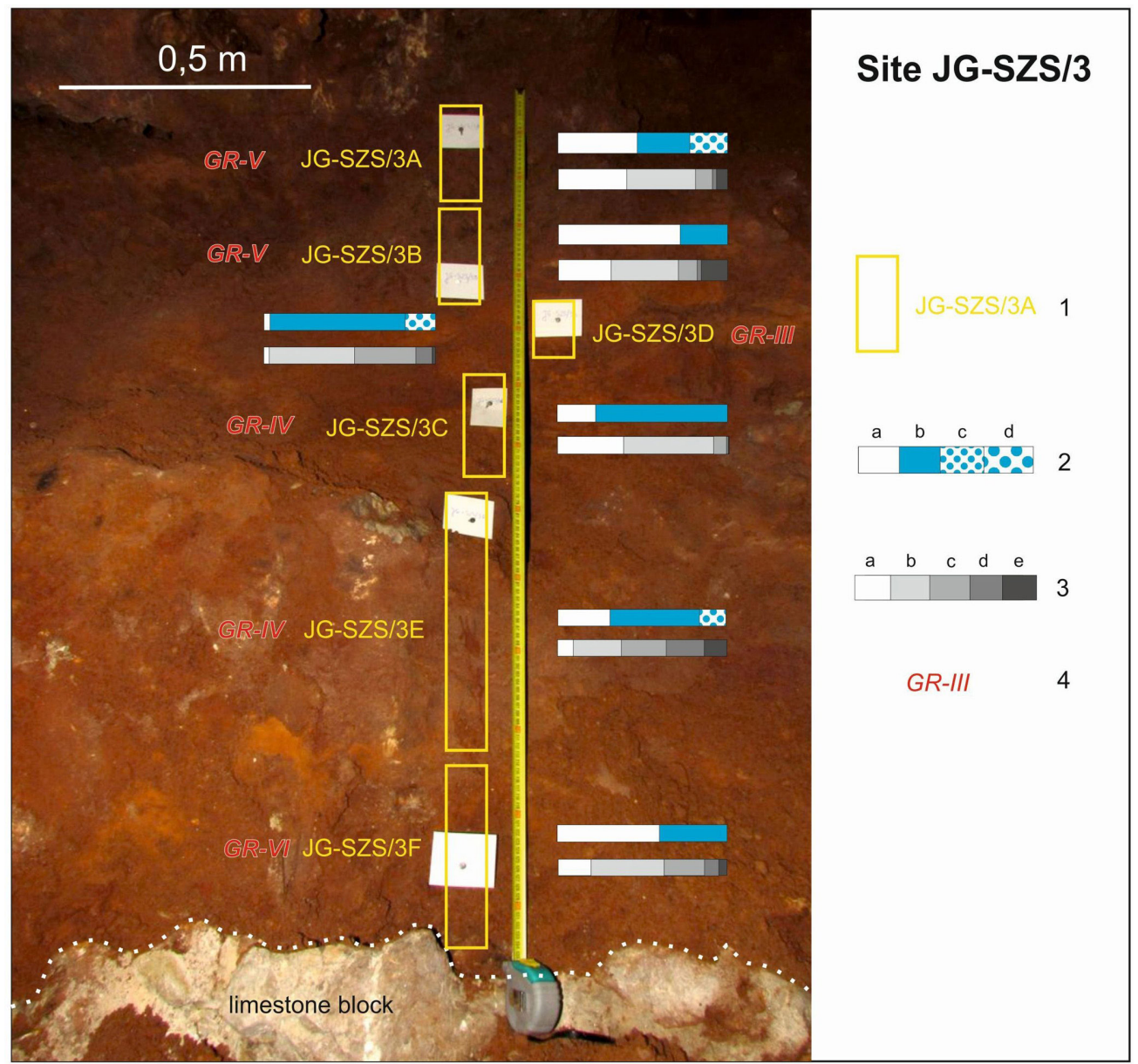

Fig. 15. Example of the documentation site (site no. JG-SZS/3) in the Jaskinia Głęboka Cave. Explanation of symbols: 1 - sampling place with its symbol; 2 - grains size distribution of a sample - main fractions ( $\mathrm{a}$ - silt and clay, $\mathrm{b}$ - sand, $\mathrm{c}$ - pebbles/debris, $\mathrm{d}-\mathrm{rubble})$; 3 - grain size distribution of a sample - sand fractions ( - very fine, $b$ - fine, $c$ - medium, $d$ - coarse, e - very coarse); 4 - symbol of lithological unit (GR-III - brown and rust-coloured sands, GR-IV - silty sands, GR-V - rusty-brown sandy silts, GR-VI - red and red-brown sandy silt)

In the same place, there is a described collection of microfossils and whole photographic and drawing documentation.

\section{Formal, scientific and practical results}

\section{Underground Touristic Trail in the Kadzielnia Park}

The state of the scientific documentation and supervision of preparatory works of the Underground Touristic Trail was recapitulated each year in archival manuscripts (Urban, Kasza - archival data). The final scientific results of these works were published in the paper (Urban et al., 2011a) and the book (Urban et al., 2011b). During these works, 52 documentation sites were registered; most of them (more than 40) represented the depositional sequences in cave sediment cross-sections (Fig. 6), several were points of sampling (mainly speleothems). In total,
138 samples were taken in these sites and almost all were stored in the archival collection. However, parts from 74 samples were used for grain size analysis and petrograhic observations. All samples in which the Quaternary fossils were found, i.e. 27 ones, were examined by palaeontologist (K. Ochman). The fossils were represented exclusively by bat bones, among which only teeth (i.e. microfossils identified using a binocular) and very rare elements of skulls could be used for the taxonomic identification. Some specimens were also used for more advanced laboratory analyses, such as: analysis of heavy minerals (one sample of sand), petrographic, microscopic observation of lithified rocks (six thin-sections), X-ray analysis (six samples of clayey and ferruginous-manganese sediments), U-series dating (10 analyses of four samples of calcite speleothems performed and interpreted by H. Hercman). There was no reason to stop the technical exploration and digging due to the finding of a very important palaeontological site during the preparatory work. 
The scientific study of the morphologies of conduits, cave sediments as well as lithology and structures of host rocks made it possible to describe of the principal speleogenetic features of the karst system. The explored system of conduits formed due to the water circulation along the fault (and associated fractures) in the shallow phreatic zone. This karst system formed during the Neogene (surely not after the Early Pleistocene) under different hydrological circumstances, when the ground relief and network of stream valleys differed much from current morphology. The oldest secondary elements found in the caves are calcite speleothems, as well as marl filling the karst fissure that is cave lacustrine sediment. The U-series dating of speleothem samples proved that some of them are older than $350 \mathrm{ka}$, probably older than $1.2 \mathrm{Ma}$, some other ranges 150-300 ka. In turn, the palaeontological study of bone-breccia in lacustrine marl suggests its Early Pleistocene age (Urban et al. 2011a, b).

Most sediments filling the studied karst system represent the Late Pleistocene and the Holocene, which is proved by their lithology and, most of all, taxonomic assemblage of bat fossils. Among these sediments clayey-debris sediments predominate. They are composed of rock clasts that reached the caves due to the gravitational fall of cave ceilings partly formed of rocks of the Famennian limestone-marl-clay series. Below these clayey debris and within low, tributary cavities, two types of sediments occur: beige or beige-brown muds and red or brown clays. The muds resemble loess washed into the caves in the Late Pleistocene or at the beginning of the Holocene. The clays are sediments formed due to the surface weathering of Devonian limestones and limestone-marl-clay series. These residual sediments were then transported into the caves by flowing or seeking water. The assemblage of fossils found in these sediments represent bat species currently living in Poland (since the Pleistocene) that prefer forest habitats and areas situated close to the stream or water basins. Such fossil communities have not yet been studied in the caves of the region (Urban et al., 2011a, b).

The observations and description of other geological phenomena: Devonian sedimentary structures, as well as tectonic and hydrothermal mineralisation elements provide sufficient data to prepare a comprehensive educational interpretation, such as a scientific book (Urban et al., 2011b), popular book (Urban et al., 2013), or observation sites in the trail, panels and guiding (Figs 6, 7).

\section{Jaskinia Gtęboka in the "Góra Zborów" nature reserve}

A team of experts established to supervise the technical work and documentation in Jaskinia Głęboka finished their work with a report (manuscript) forwarded to the Society of the Zawiercie Region Fellows, managing the cave on behalf of the Authority of Regional Directorate for Environmental Protection in Katowice (Bzowska et al., 2012). Some advanced analyses were (or even still are) performed after the technical work was finished. The only first results related to speleothems dating and isotope analyses were presented on the Speleological Symposia of the Speleological Section, Polish Society of Naturalists (Błaszczyk et al., 2015, 2016). All other scientific results are still in preparation and have not been published, yet.

During the technical work that prepared a new touristic trail in the cave, 28 documentation sites were registered (26 sequences of unconsolidated or solid sediments and two flowstone profiles); most of them in the part where the new passage was dug (Fig. 10). From samples collected in these documentation sites, 42 were separated for granulometric analyses and petrographic observations carried out by geologist J. Urban. 19 samples collected in one layer of depositional sequences along the excavated passage, situated close to the top of the whole depositional sequence, were examined by palaeontologist (K. Ochman) to identify Quaternary (Holocene) fossils, bats mainly. 34 samples of sediments and solid deposits from the cave were examined by X-ray analysis and microscopic analysis of thin-sections, made by G. Bzowska and T. Krzykawski to discover the mineral composition. Two profiles of thick flowstone covers (104 cm of upper profile in the Korytarz Wejściowy passage and $52 \mathrm{~cm}$ of lower profile in Sala Południowa chamber) were used for U-series dating and stable isotope analyses, conducted by $\mathrm{H}$. Hercman and her team.

The studies performed during the scientific documentation of technical work in Jaskinia Głęboka support a hypothesis of the hypogene stage of the evolution of the caves in the region of the Kraków-Częstochowa Upland (e.g. Tyc, 2009). Almost the whole Jaskinia Głęboka is filled with sediments (unconsolidated or cemented by calcite), as well as solid rocks, various speleothems (e.g. flowstones, dripstones; Fig. 13), so the empty space (with a touristic trail and other infrastructure) is situated close to the ceiling (partly collapsed) of a larger cavity. All entrances (also that closed during the show cave arrangement) of the cave are artificial, and the natural entrance(s) is probably very narrow and blocked by sediments. According to the results of granulometric, lithological, petrographic and mineralogical studies of sediments collected during the technical work, it can be stated that the source of the cave sediments were sandstone weathering debris and karst residual sediments from the surface. Mixing of different types (grain size and roundness), as well as chaotic in places arrangement of the most of sediments can suggest, most probably, that they are the results of mud flows or other high energy flows from surface to the cavity. U-series dating supported by the oxygen isotope stratigraphy allowed the authors to estimate the crystallization age of the flowstone covering these sediments in a range of 500-1200 ka BP (Błaszczyk et al., 2016). 
The preliminary results of the documentation and scientific studies performed in Jaskinia Głęboka during the technical work provided information for the preparation of comprehensive educational sites along the touristic trail in the cave as well as outside, in the waiting point close to the cave entrance. Both profiles of flowstones were polished and the results of $\mathrm{U}$-series dating were used to indicate the age of some important layers.

\section{Discussion and recommendations}

The scope of the documentation, scientific analyses and results performed during the preparatory works in the Underground Touristic Trail and Jaskinia Głęboka were less than in the cases of Raj and Jaskinia Niedźwiedzia, that were arranged as show caves approximately 30 and 40 years ago. This was caused by smaller sample of scientific evidence found in the analysed caves, most of all the lack of archaeological artefacts and macrofossils - bones of large animals. Nevertheless, the proposed procedures assumed the occurrence of such scientific elements and resulted in a prompt reaction, namely changes in technical work in order to record such an archaeological or palaeontological site and preserve its artefacts. The obtained scientific data seem to be adequate to the material "trapped" in the modified parts of the karst systems. Moreover, the collected archival samples together with the detailed description of sites and sampling, provide material for potential scientific examination using new analytical methods (not yet discovered). The documentation and analytical works conducted in both study sites meet good practices and legal regulations implemented in other countries and presented in manuals (e.g. Cave conservation..., 1995; Hildreth-Werker \& Werker, 2006; www1; www2; www3; www4), recently proposed also in Poland (Tyc, 2016a, b). These procedures, if realized in agreement with local conservation administration, are also in accordance with Polish legislation, which requires the preservation of archaeological records in sediments (art. 32, 33, Ustawa o ochronie zabytków i opiece nad zabytkami, 2003) and fossils (art. 121, 122, 131, Ustawa o ochronie przyrody, 2004).

Recapitulating the experiences of former Polish preparatory work in tourist show caves (Studies..., 1972; Rubinowski, 1974; Jahn et al., 1989) and our work, as well as considering the good practices applied in other countries, hereafter we recommend the procedure, which should be followed during all exploration and technical work performed in caves, which generate modifications of cave morphology or sediments:

- All exploration and technical work that modify morphology and sediments of caves must be performed with permission of the appropriate conservation administration and supervised by experts.
- The principal elements of the scientific supervision of such work include the documentation of the original morphology of cave and lithology of its sediments outcropped due to the work (photography, measurements, drawings, description), as well as sampling of each type of sediments in the depositional sequences. Such documentation must be done along with the progress of exploration or technical work (digging).

- The weight of samples of clayey-silty-sandy sediments should be not less than $2 \mathrm{~kg}$. They should be divided into two specimens: archival (stored in the archive of samples) and analytical, used for laboratory examination.

- The basic examination of the analytical sample that would allow the detection of unique fossils, minerals or rocks in the sediments, should be performed as soon as possible in order to potential stop sediment destruction and to conduct additional sampling or other documentation of the original site.

- All other laboratory analyses can be performed, if possible and necessary, up to the complete consumption of the analytical samples.

Similar procedures can be kept in case of work in artificial cavities, however in such cavities, the morphology and construction/lithology of the walls and ceilings are usually the most characteristic elements that determine genetic conclusions, whereas sediments are often absent or rare. Nevertheless, in such cavities, small agglomerations of sediments or even single fragments of natural or artificial elements could play a crucial role in the reconstruction of their development and history.

\section{Conclusions}

The scientific supervision of exploratory and technical work in caves of the Kadzielnia Park (present-day Underground Touristic Trail) and Jaskinia Głęboka confirmed the idea that the documentation and scientific examination of modified parts of caves and cave sediments are necessary activities so as not to lose very important geological-palaeontological records "trapped" in cave's morphology and sediments. The necessity of such scientific supervision is also suggested by the results of similar earlier activities in tourist show caves in Poland, as well as good practices implemented in other countries. Furthermore, this is required by Polish legislation.

As a consequence, the procedure of scientific supervision is recommended. The principal element of this procedure is documentation of original cave morphology and lithology and sequence of cave sediments, as well as sampling of all lithological types of sediments modified or destroyed due to the exploration or technical works. Archival (stored) and analytical specimens should be sampled. The basic analyses 
of petrographical, palaeontological and archaeological content of samples should be conducted practically along with the progress of technical work in the cave, to make possible additional scientific examination and sampling of the most interesting sites before their destruction. In this way, the geological evidence "trapped" in the cave's sediments and shape can be properly recorded, and thus, the geological heritage of the cave will not be lost.

\section{References}

Błaszczyk M., Hercman H., Aninowska M., Kicińska D., Gąsiorowski M., Pawlak J. \& Tyc A., 2015. Wstępna rekonstrukcja warunków paleośrodowiska w rejonie Jaskini Głębokiej na podstawie badań izotopowych nacieków. In: Kicińska D., Stefaniak K. \& Szynkiewicz A. (eds), Materiaty 49. Sympozjum Speleologicznego. Sekcja Speleologiczna Polskiego Towarzystwa Przyrodników im. Kopernika, Załęcze Wielkie, 79.

Błaszczyk M., Hercman H., Pawlak J., Gąsiorowski M., Aninowska M., Kicińska D. \& Tyc A., 2016. Rekonstrukcja warunków paleoklimatycznych dolnego i środkowego plejstocenu na podstawie badań izotopowych i analiz mikrofacjalnych polewy z Jaskini Głębokiej (Jura Krakowsko-Częstochowska). In: Urban J. (ed.), Materiaty 50. Sympozjum Speleologicznego. Sekcja Speleologiczna Polskiego Towarzystwa Przyrodników im. Kopernika, 100.

Bzowska G., Hercman H., Krzykawski T., Nowak J., Ochman K., Socha P., Ślusarczyk M., Tyc A., Urban J., Urbanowski M., Waga J.M. \& Gardocki M., 2012. Ekspertyza dotycząca wykonania badań naukowych w ramach nadzoru nad realizacją zadania - udostępnienie do ruchu turystycznego kolejnych partii Jaskini Głębokiej, tj. Sali z Obniżeniem Stropu, korytarzyka Esso oraz Sali za Esso, w rezerwacie przyrody Góra Zborów. Sosnowiec.

Caveconservation policy. 1995. National Caving Association, London.

Głazek J., 1973. Znaczenie zjawisk krasowych dla rekonstrukcji paleogeograficznych i paleotektonicznych. Przegląd Geologiczny 10: $517-523$.

Hildreth-Werker V. \& Werker J.C., 2006. Cave conservation and restoration. National Speleological Society, Huntsville.

Jahn A., Kozłowski S. \& Wiszniowska T. (eds), 1989. Jaskinia Niedźwiedzia w Kletnie. Zakład Narodowy im. Ossolińskich, Wrocław.

Kowalski K., 1951. Jaskinie Polski, vol. I. Państwowe Muzeum Archeologiczne, Warszawa.

Krajewski M. \& Matyszkiewicz J., 2009. Upper Jurassic deposits in the Częstochowa Upland. In: Stefaniak K., Tyc A. \& Socha P. (eds.), Karst of the Częstochowa Upland and eastern Sudetes. Studies of the Faculty of Earth Sciences University of Silesia, No. 56: 37-56.

Matyja B.A. \& Wierzbowski A., 2004. Stratygrafia i zróżnicowanie facjalne utworów górnej jury Wyżyny Krakowsko-Częstochowskiej i Wyżyny Wieluńskiej. In: Partyka J. (ed.), Zróżnicowanie i przemiany środowiska przyrodniczo-kulturowego Wyżyny Krakowsko-Częstochowskiej, t. 1. Przyroda, Ojcowski Park Narodowy, Ojców: 13-18.

Rubinowski Z. (ed.), 1974. Badania i udostęnienie jaskini Raj. Wydawnictwa Geologiczne, Warszawa.

Studies on Raj Cave near Kielce (Poland) and its deposits, 1972. Folia Quaternaria, 41.
Sznober N. \& Tyc A., 2010. Jaskinia Głęboka w rezerwacie przyrody Góra Zborów. Jaskinie, 4(61): 29-33.

Tyc A., 2009. Karst and caves of Częstochowa Upland - morphology and the outline of speleogenesis. In: Stefaniak K., Tyc A. \& Socha P. (eds), Karst of the Częstochowa Upland and eastern Sudetes. Studies of the Faculty of Earth Sciences University of Silesia, No. 56: 11-36.

Tyc A., 2016a. Osady jaskiniowe - obiekt szczególnej troski podczas eksploracji jaskiń. In: Słupińska M. (ed.), Natura jaskiń, czyli aspekty przyrodnicze $w$ taternictwie jaskiniowym. Fundacja Speleologia Polska, Sosnowiec: 61-65.

Tyc A., 2016b. Dobre praktyki w taternictwie jaskiniowym - aspekty przyrodnicze. In: Słupińska M. (ed.), Natura jaskiń, czyli aspekty przyrodnicze $w$ taternictwie jaskiniowym. Fundacja Speleologia Polska, Sosnowiec: 127-132.

Urban J., 2004. Caves and karst sites of Poland as a contribution to geological heritage of central Europe. Polish Geological Institute Special Papers, 13: 89-96.

Urban J., 2006. Prawna i praktyczna ochrona jaskiń w Polsce. Chrońmy Przyrodę Ojczysta, 62, 1: 53-72.

Urban J., 2014. Cechy rzeźby strukturalnej Gór Świętokrzyskich oraz południowo-wschodniej części Niecki Nidziańskiej. Przegląd Geologiczny, 62, 44-50.

Urban J. \& Gągol J., 2008. Geological heritage of the Świętokrzyskie (Holy Cross) Mts (Central Poland). Przeglad Geologiczny 56, 8/1: 618-628.

Urban J., Kasza A., Ochman K. \& Hercman H., 2011a. Kenozoiczny kras Kadzielni. In: Ludwikowska-Kędzia M. \& Wiatrak M. (eds), Geologia i geomorfologia regionu świętokrzyskiego, Instytut Geografii Uniwersytetu Jana Kochanowskiego w Kielcach, Kielce: 9-28.

Urban J., Kasza A., Ochman K. \& Malec J., 2011b. Jaskinie Kadzielni. Geopark Kielce, Kielce.

Urban J., Kasza A., Ochman K., Malec J. \& Wołoszyński M., 2013. Kadzielnia i jej jaskinie. Manufaktura Geoturystyczna, Warszawa.

Ustawa o ochronie zabytków i opiece nad zabytkami, 2003. Dz. U. z 2003 r., Nr 162, poz. 1568.

Ustawa o ochronie przyrody, 2004. Dz. U. z 2004, Nr 92, poz. 880; z 2018 r., poz. 142.

www1 - http://www.goodearthgraphics.com/virtcave/conserve/conserve.html

www2 - http://www.sat.dundee.ac.uk/ arb/speleo/conservation.html www3 - http://www.academia.edu/1823816/Legislation_for_Karst_ and_cave_protection_in_Europe_and_other_countries

www4 - https://portals.iucn.org/library/sites/library/files/documents/ 1997-026.pdf

This paper is extended versions of presentations delivered during the III Forum GEO-PRODUKT: "From geoeducation to innovation", which was held on September, 22-24, 2017 in Wojsławice, Poland (Sudetic Foreland Geopark). For details, please, visit the webpage http://geoprodukt2017.geopark.org.pl.

Niniejszy artykuł stanowi rozszerzenie referatu wygłoszonego w ramach III Forum GEO-PRODUKT: „Od geoedukacji do innowacji”, które odbyło się w dniach 22-24 września 2017 roku w Wojsławicach, Geopark Przedgórze Sudeckie (http://geoprodukt2017.geopark.org.pl). 